\title{
Selenium Health Benefit Values: Updated Criteria for Mercury Risk Assessments
}

\author{
Nicholas V. C. Ralston ${ }^{1}$ • Carla R. Ralston ${ }^{1}$ - Laura J. Raymond ${ }^{1}$
}

Received: 7 October 2014 / Accepted: 14 September 2015 / Published online: 13 October 2015

(C) Springer Science+Business Media New York 2015

\begin{abstract}
Selenium (Se)-dependent enzymes (selenoenzymes) protect brain tissues against oxidative damage and perform other vital functions, but their synthesis requires a steady supply of Se. High methylmercury $\left(\mathrm{CH}_{3} \mathrm{Hg}\right)$ exposures can severely diminish Se transport across the placenta and irreversibly inhibit fetal brain selenoenzymes. However, supplemental dietary Se preserves their activities and thus prevents pathological consequences. The modified Se health benefit value $\left(\mathrm{HBV}_{\mathrm{Se}}\right)$ is a risk assessment criterion based on the molar concentrations of $\mathrm{CH}_{3} \mathrm{Hg}$ and Se present in a fish or seafood. It was developed to reflect the contrasting effects of maternal $\mathrm{CH}_{3} \mathrm{Hg}$ and $\mathrm{Se}$ intakes on fetal brain selenoenzyme activities. However, the original equation was prone to divide-by-zero-type errors whereby the calculated values increased exponentially in samples with low $\mathrm{CH}_{3} \mathrm{Hg}$ contents. The equation was refined to provide an improved index to better reflect the risks of $\mathrm{CH}_{3} \mathrm{Hg}$ exposures and the benefits provided by dietary Se. The $\mathrm{HBV}_{\mathrm{Se}}$ provides a biochemically based perspective that confirms and supports the FDA/EPA advice for pregnant and breast-feeding women regarding seafoods that should be avoided vs. those that are beneficial to consume. Since Se can be highly variable between watersheds, further evaluation of freshwater fish is needed to identify locations where fish with negative $\mathrm{HBV}_{\mathrm{Se}}$ may arise and be consumed by vulnerable subpopulation groups.
\end{abstract}

Keywords Selenium · Selenoenzymes · Methylmercury · Brain $\cdot$ Seafood $\cdot$ Fish

Nicholas V. C. Ralston nick.ralston@und.edu

1 University of North Dakota, Grand Forks, ND 58202, USA

\section{Introduction}

Selenium (Se)-dependent protection against otherwise lethal effects of high mercury $(\mathrm{Hg})$ exposures was first described in 1967 [1], and soon afterwards, it was shown that high $\mathrm{Hg}$ or methyl- $\mathrm{Hg}\left(\mathrm{CH}_{3} \mathrm{Hg}\right)$ exposures severely diminished Se transport across the placenta $[2,3]$. Although the nutritional essentiality of Se has been known since 1957 [4], the importance of tissue $\mathrm{Hg}$ :Se molar ratios in relation to $\mathrm{Hg}$ toxicity was not described until it was recognized that Se-dependent enzymes (selenoenzymes) were inhibited by $\mathrm{Hg}$ [5]. It was subsequently noted that when $\mathrm{Se}$ and $\mathrm{Hg}$ are coadministered, insoluble and biologically unavailable $\mathrm{HgSe}$ complexes formed in blood and tissues [6,7]. Although this mechanism was initially misinterpreted as Se sequestering $\mathrm{Hg}$, thereby rendering $\mathrm{Hg}$ unable to impose harm, numerous studies have since confirmed that $\mathrm{Hg}$ sequesters Se [8-11] and thereby inhibits the activities of selenoenzymes, which are vitally important for brain health and functions [12-14]. Animal studies of maternal $\mathrm{CH}_{3} \mathrm{Hg}$ exposures have revealed that fetal brain selenoenzyme activities are far more sensitive to $\mathrm{CH}_{3} \mathrm{Hg}$ inhibition than those of adults $[15,16]$, and once fetal brain selenoenzyme activities are inhibited, they are not readily restored [17]. Irreversible inhibition of selenoenzyme activities and its biochemical sequelae are well characterized [14, 18, 19] and appear to be the primary mechanism of $\mathrm{CH}_{3} \mathrm{Hg}$ toxicity $[14,20]$.

The Se health benefit value, or Se-HBV [21], is a recently developed risk assessment criterion that was developed to enable concurrent consideration of $\mathrm{CH}_{3} \mathrm{Hg}$ exposures and dietary Se intakes, particularly in regard to maternal consumption during pregnancy. Dietary $\mathrm{Se}$ and $\mathrm{Hg}$ have opposing effects on Se status and brain selenoenzyme activities. Therefore, this equation is used to provide an index (Se$\mathrm{HBV}$ ) to predict effects of maternal $\mathrm{CH}_{3} \mathrm{Hg}$ exposures from 
seafood consumption [22]. The equation was modified to reflect variances in $\mathrm{CH}_{3} \mathrm{Hg}$ and $\mathrm{Se}$ concentrations and eliminate disproportionality otherwise encountered in samples with low $\mathrm{Hg}$ levels. Because the equation employs Se:Hg molar ratios, the Se-HBV can become disproportionate when $\mathrm{Hg}$ concentrations are very low in relation to Se. The modified equation has the virtue of accurately indicating the amount of Se in excess of $\mathrm{CH}_{3} \mathrm{Hg}$ present in that food and is designated $\mathrm{HBV}_{\mathrm{Se}}$ to distinguish it from the original equation. Since $\mathrm{Hg}$ does not quantitatively sequester $\mathrm{Se}$, the $\mathrm{HBV}_{\text {Se }}$ provides a highly conservative index for establishing food safety considerations. This article details the enhanced reliability of the updated $\mathrm{HBV}_{\mathrm{Se}}$ index and compares the Se-HBV and $\mathrm{HBV}_{\mathrm{Se}}$ of ocean fish and other seafoods for reference purposes.

\section{Methods}

\section{Modification of the Selenium Health Benefit Value Equation}

Neurological effects in children have been associated with $\mathrm{CH}_{3} \mathrm{Hg}$ exposures from maternal consumption of seafoods that contain $\mathrm{CH}_{3} \mathrm{Hg}$ in sufficient excess to induce a conditioned Se deficiency in placental and fetal tissues. This does not occur when adequate amounts of maternal Se are available for transport to the fetus. Assessments based only on $\mathrm{CH}_{3} \mathrm{Hg}$ exposures [23] may indicate risks in situations where they do not exist and do not indicate risks that are accentuated by poor dietary Se intakes. The Se-HBV was developed as a more accurate index of the relative risks or benefits expected in association with seafood or freshwater fish consumption because it considers the absolute and relative molar amounts of $\mathrm{CH}_{3} \mathrm{Hg}$ and Se that are present [21]:

$\mathrm{Se}-\mathrm{HBV}=(\mathrm{Se} \times[\mathrm{Se} / \mathrm{Hg}])-(\mathrm{Hg} \times[\mathrm{Hg} / \mathrm{Se}])$

This equation yields positive values when the amount of $\mathrm{Se}$ present in the fish is in excess of $\mathrm{Hg}$, thereby indicating health risks that might otherwise accompany $\mathrm{CH}_{3} \mathrm{Hg}$ exposures are negated. Negative values indicate the seafood's $\mathrm{CH}_{3} \mathrm{Hg}$ concentrations are in excess of Se; thus, maternal consumption of that food does not offer protection from its $\mathrm{CH}_{3} \mathrm{Hg}$ content but could instead induce a temporary interruption or decrease in Se transport to the fetus. However, assessing the Se-HBV becomes problematic when the $\mathrm{Hg}$ content of the sample is at or below the detection limit. In such cases, the Se:Hg molar ratio approaches infinity and the $\mathrm{Hg}$ :Se ratio approaches zero, resulting in an erroneously high value that exaggerates the health benefits of increased dietary Se. Furthermore, since excessive Se intakes can be associated with health consequences, it is essential to have an index that appropriately reflects the amounts of dietary Se provided. The effects associated with consumption of a seafood with a negative Se-HBV or $\mathrm{HBV}_{\mathrm{Se}}$ depend on the $\mathrm{CH}_{3} \mathrm{Hg}$ in excess of Se but are also dependent on the absolute amount of Se available. For example, the adverse effects of eating seafood containing $5.5 \mu \mathrm{mol} \mathrm{CH} \mathrm{CH}_{3} \mathrm{Hg} / \mathrm{kg}$ with $0.5 \mu \mathrm{mol} \mathrm{Se} / \mathrm{kg}$ would be greater than eating seafood containing $15.5 \mu \mathrm{mol} \mathrm{CH} \mathrm{CH}_{3} \mathrm{Hg} / \mathrm{kg}$ with $10.5 \mu \mathrm{mol} \mathrm{Se} / \mathrm{kg}$. Although both instances involve a Se deficit of $5 \mu \mathrm{mol} / \mathrm{kg}$, the second example involves a higher $\mathrm{CH}_{3} \mathrm{Hg}$ exposure albeit less associated risk due to the additional $\mathrm{Se}$ available for distribution to fetal tissues. In certain circumstances, continual high intakes of Se might have adverse effects, so an index that reflects the amount of Se that is biologically available also needs to be reflected by the $\mathrm{HBV}_{\mathrm{Se}}$ of the fish being consumed. Thus, both the $\mathrm{CH}_{3} \mathrm{Hg}$ and the Se concentration are crucial aspects of this index. For that reason, the equation for calculating the index was refined in order to (1) incorporate relative and absolute amounts of $\mathrm{Hg}$ and $\mathrm{Se}$, while eliminating the molar ratios that can result in disproportionately high values as a consequence of very low $\mathrm{Hg}$ concentrations, and (2) provide an indication of the net Se surplus or deficit. This approach provides a straightforward assessment of $\mathrm{Se}$ availability and provides a value that indicates the magnitude of the relative Se deficit or surplus for such seafoods or fish.

To determine whether the amounts of $\mathrm{CH}_{3} \mathrm{Hg}$ and Se present in the seafood would potentially result in a Se deficit or a net surplus, it is necessary to incorporate the difference in their molar concentrations. Through the use of Se in the denominator, the absolute molar concentration present in the food is recognized, while the result also provides an indication of the relative amount of Se available:

Relative Se availability $=([\mathrm{Se}-\mathrm{Hg}] / \mathrm{Se})$

However, in order to reflect the amount of physiological Se that is potentially provided or lost in respect to sequestration by the associated $\mathrm{Hg}$, the relative amount of Se available is multiplied by the total amount of $\mathrm{Hg}$ and Se present in the food. To differentiate this index from that provided by the original Se-HBV equation, the improved criterion is designated as $\mathrm{HBV}_{\mathrm{Se}}$ [24]:

$\mathrm{HBV}_{\mathrm{Se}}=([\mathrm{Se}-\mathrm{Hg}] / \mathrm{Se}) \times(\mathrm{Se}+\mathrm{Hg})$

The sign indicates whether the food would improve or diminish Se status while the scale of the value proportionately reflects the Se surplus or deficit associated with eating that seafood.

To demonstrate how these indices are affected by $\mathrm{CH}_{3} \mathrm{Hg}$ molar concentrations, a comparison of the calculated Se-HBV vs. $\mathrm{HBV}_{\mathrm{Se}}$ was performed using the range of $\mathrm{CH}_{3} \mathrm{Hg}$ concentrations that have been observed in various types of seafood. For purposes of this comparison, Se contents were maintained constant at $10.0 \mu \mathrm{mol} \mathrm{Se} / \mathrm{kg}$ (approximating the average Se 
content of ocean fish) in relation to a range of $\mathrm{CH}_{3} \mathrm{Hg}$ increasing from 0.125 to $9.971 \mu \mathrm{mol} / \mathrm{kg}$ ( 0.025 to $2.0 \mathrm{mg} / \mathrm{kg}$ ), shown in the log scale of Fig. 1a, and from 9.971 to $34.9 \mu \mathrm{mol} \mathrm{Hg} / \mathrm{kg}$ (2.0 to $7.0 \mathrm{mg} / \mathrm{kg}$ ), as shown in the linear scale of Fig. $1 \mathrm{~b}$.

\section{Comparative Evaluation of Selenium Health Benefit Values of Seafoods}

The Se and $\mathrm{CH}_{3} \mathrm{Hg}$ contents of various types of seafood were used to calculate the Se-HBV and $\mathrm{HBV}_{\mathrm{Se}}$ for each sample, along with their means and standard deviations. The molar concentrations of $\mathrm{CH}_{3} \mathrm{Hg}$ and $\mathrm{Se}$ present in yellowfin tuna (Thunnus albacares), bigeye tuna (Thunnus obesus), blue marlin (Makaira mazara), albacore (Thunnus alalunga), swordfish (Xiphias gladius), thresher shark (Alopias vulpinus), mako shark (Isurus oxyrinchus), and pilot whale (Globicephala melas) were used to perform side-by-side comparisons of the Se-HBV vs. $\mathrm{HBV}_{\mathrm{Se}}$. The data for the ocean fish samples were originally reported in Kaneko and Ralston [21], but the results of additional repeat analyses are included in this assessment. The pilot whale data for samples collected in 1977 and 1978 were reported by Juhlshamn et al. [25]. The 1978 data were selected by Grandjean et al. as reflective of pilot whale $\mathrm{Hg}$ exposures by the Faroese mothers during their study [26]. The Se-HBV vs. $\mathrm{HBV}_{\mathrm{Se}}$ results for these seafoods are graphically compared in Fig. 2 and shown in Table 1.

\section{Results}

\section{Comparison of $\mathrm{Se}-\mathrm{HBV}$ and $\mathrm{HBV}_{\mathrm{Se}}$}

At low $\mathrm{CH}_{3} \mathrm{Hg}$ concentrations, the Se-HBV increases exponentially as $\mathrm{Hg}$ diminishes (Fig. 1a). This increases bias as $\mathrm{Se}: \mathrm{Hg}$ molar ratios asymptotically approach infinity when $\mathrm{CH}_{3} \mathrm{Hg}$ concentrations approach zero. For that reason, the Se-HBV fails to accurately reflect the moderate nutritional benefits associated with excess Se. In contrast, the calculated $\mathrm{HBV}_{\mathrm{Se}}$ asymptotically approaches the actual Se concentration of the seafood as $\mathrm{Hg}$ contents diminish toward zero; thus, it accurately reflects the net amount of Se available. The outcomes calculated for seafoods with negative Se-HBV or $\mathrm{HBV}_{\mathrm{Se}}$ similarly reflect the diminishment in Se status potentially associated with excess of maternal $\mathrm{CH}_{3} \mathrm{Hg}$ intakes (Fig. 1b).

\section{Comparison of Se-HBV and $\mathrm{HBV}_{\mathrm{Se}}$ of Seafoods}

Although the $\mathrm{Hg}$ contents of ocean fish species such as yellowfin tuna, bigeye tuna, blue marlin, albacore tuna, and thresher shark vary dramatically (Table 1 ), their $\mathrm{HBV}_{\mathrm{Se}}$ indicates they are all a net source of surplus Se and are thus predicted to protect against risks associated with $\mathrm{CH}_{3} \mathrm{Hg}$ exposures. However, swordfish do not consistently provide Se in excess of $\mathrm{CH}_{3} \mathrm{Hg}$ and therefore are not advised for mothers to consume during pregnancy. The negative $\mathrm{HBV}_{\mathrm{Se}}$ consistently observed for mako shark and pilot whale meats indicates that their consumption could compromise fetal Se supply. Thus, consumption of these seafoods should be limited during pregnancy.

The standard deviations of the Se-HBV and $\mathrm{HBV}_{\mathrm{Se}}$ for the seafood examples shown in Table 1 and Fig. 2 indicate a much higher variability of Se-HBVs in comparison to $\mathrm{HBV}_{\mathrm{Se}}$ results. Variability between the two indices was primarily driven by disproportionately high Se-HBVs calculated for seafoods that had low $\mathrm{CH}_{3} \mathrm{Hg}$ contents relative to Se (Table 1). For example, the Se-HBV of the bigeye tuna samples was uniformly positive but had a standard deviation that was greater than their sample mean and a coefficient of variability $(\mathrm{CV})$ of $122 \%$ (ranging from 8.6 to 594). In contrast, the $\mathrm{HBV}_{\mathrm{Se}}$ for these same samples ranged from 2.4 to 36.5 , with a $\mathrm{CV}$ of $33 \%$. Since the ocean food web is rich in Se and tissue Se contents are homeostatically regulated, few seafoods have Se concentrations below $2 \mu \mathrm{mol} \mathrm{Se} / \mathrm{kg}$. For that reason, negative $\mathrm{Se}-\mathrm{HBV}$ are not prone to the exponential increases due to divide-by-zero-type errors such as those that occurred for certain seafoods with positive Se-HBVs. Thus, seafoods that contain more Se than $\mathrm{CH}_{3} \mathrm{Hg}$ tend to have negative Se-HBV and $\mathrm{HBV}_{\mathrm{Se}}$ values that are more or less equivalent. To summarize the comparisons of these seafoods, the differences

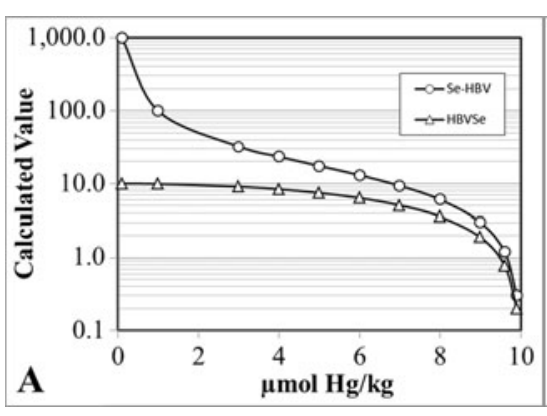

Fig. 1 Comparison of the effects of $\mathrm{Hg}$ concentrations on calculated Se$\mathrm{HBV}$ and $\mathrm{HBV}_{\mathrm{Se}}$ in a sample with $10.0 \mu \mathrm{mol} \mathrm{Se} / \mathrm{kg}$. a The divergent effects that occur when $\mathrm{Hg}$ is at low to near equimolar stoichiometry

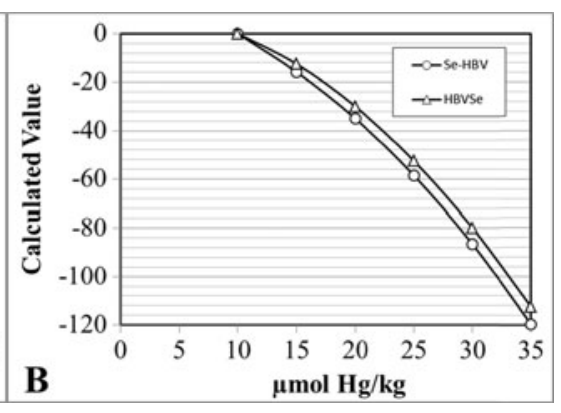

(shown in $\log$ scale). b The near equivalence of the two indices when $\mathrm{Hg}$ concentrations exceed equimolar stoichiometry with Se 
Fig. 2 Comparison of the calculated Se-HBV and $\mathrm{HBV}_{\mathrm{Se}}$ of selected seafoods. Ocean fish data compared in this figure are from Kaneko and Ralston [21], while pilot whale data originate from Julshamn et al. [25]

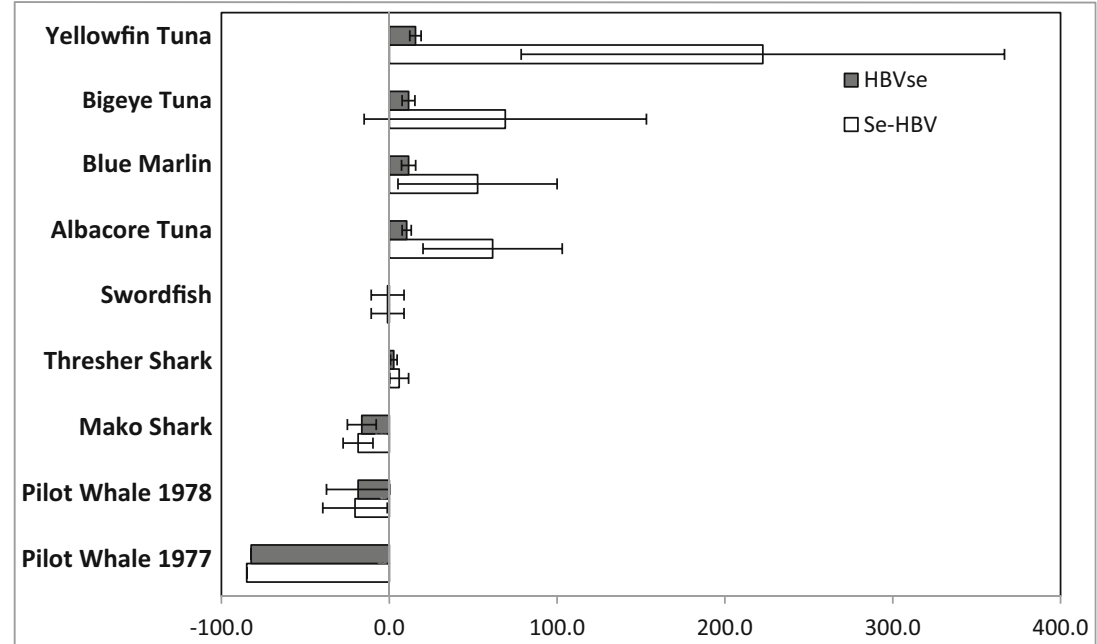

between $\mathrm{Se}-\mathrm{HBV}$ and $\mathrm{HBV}_{\mathrm{Se}}$ were greatest for samples with highly positive values, but differences decreased as the magnitude of their calculated values diminished and were negligible for seafoods with negative values (Fig. 1). The Se-HBV and $\mathrm{HBV}_{\mathrm{Se}}$ for the pilot whale data from 1977 shown in Table 1 and Fig. 2 reflect the results based on the mean $\mathrm{CH}_{3} \mathrm{Hg}$ and Se contents that were reported for these samples. For that reason, the standard deviations for those samples were not established.

The $\mathrm{HBV}_{\mathrm{Se}}$ results were uniformly positive for all ocean fish other than mako shark and swordfish. Because Se is homeostatically regulated in vertebrates while $\mathrm{Hg}$ bioaccumulates in relation to increasing age and weight, the $\mathrm{HBV}_{\mathrm{Se}}$ of most varieties of fish and other forms of aquatic life tend to diminish as they grow larger. Blue marlin was a unique exception. The amount of Se in its fillets remained in excess of $\mathrm{CH}_{3} \mathrm{Hg}$ at a near-constant amount, and their $\mathrm{HBV}_{\mathrm{Se}}$ remained consistent (11.46 \pm 4.18$)$ even though their $\mathrm{CH}_{3} \mathrm{Hg}$ contents ranged from $<1.0 \mu \mathrm{mol} / \mathrm{kg}$ to more than $60 \mu \mathrm{mol} / \mathrm{kg}$. The concentration of $\mathrm{CH}_{3} \mathrm{Hg}$ in the fillets approached equimolar stoichiometries with $\mathrm{Se}(\sim 10 \mu \mathrm{mol} / \mathrm{kg})$, but the Se concentrations consistently remained in excess of $\mathrm{CH}_{3} \mathrm{Hg}$ by $6.00 \pm$ $4.05 \mu \mathrm{mol} / \mathrm{kg}$. The $\mathrm{HBV}_{\mathrm{Se}}$ of mako shark samples were uniformly negative but demonstrated a downtrend in $\mathrm{HBV}_{\mathrm{Se}}$ that accompanied increasing $\mathrm{CH}_{3} \mathrm{Hg}$ bioaccumulation. The $\mathrm{HBV}_{\mathrm{Se}}$ of swordfish diminished with increasing body weight and particularly with increasing $\mathrm{CH}_{3} \mathrm{Hg}$ ( $F=199$, $\left.p=9.8 \times 10^{-19}\right)$. However, the highest $\mathrm{HBV}_{\mathrm{Se}}$ was not observed in the smallest swordfish, nor were the most negative values observed in the largest specimens.

Among pilot whales, only calves had positive values, while the $\mathrm{HBV}_{\mathrm{Se}}$ of meats from adults were uniformly negative. $\mathrm{CH}_{3} \mathrm{Hg}$ concentrations tended to increase in relation to body weight while tissue Se concentrations remained constant or diminished slightly. Therefore, the Se deficit potentially associated with pilot whale meats were significantly $(F=9.1$,
Table 1 Seafood $\mathrm{Hg}$ and $\mathrm{Se}$ contents, and $\mathrm{HBV}_{\mathrm{Se}}$

\begin{tabular}{lcccc}
\hline Common name of seafood & Number & $\begin{array}{l}\mu \mathrm{mol} \mathrm{Hg} / \mathrm{kg} \\
\text { Mean } \pm \text { SD }\end{array}$ & $\begin{array}{l}\mu \mathrm{mol} \mathrm{Se} / \mathrm{kg} \\
\text { Mean } \pm \text { SD }\end{array}$ & $\begin{array}{l}\mathrm{HBV} \\
\text { Mean } \pm \text { SD }\end{array}$ \\
\hline Yellowfin & 50 & $1.51 \pm 0.88$ & $15.80 \pm 3.44$ & $15.6 \pm 3.4$ \\
Bigeye & 50 & $3.00 \pm 1.23$ & $12.38 \pm 3.48$ & $10.0 \pm 5.3$ \\
Blue marlin & 50 & $11.88 \pm 14.96$ & $20.17 \pm 14.78$ & $11.5 \pm 4.2$ \\
Albacore & 20 & $2.49 \pm 1.18$ & $11.11 \pm 2.40$ & $10.4 \pm 2.7$ \\
Thresher shark & 10 & $4.86 \pm 1.60$ & $6.55 \pm 1.51$ & $2.7 \pm 2.0$ \\
Swordfish & 50 & $5.32 \pm 2.98$ & $5.43 \pm 1.48$ & $0.0 \pm 11.5$ \\
Mako shark & 10 & $9.01 \pm 1.99$ & $4.07 \pm 0.48$ & $-16.4 \pm 8.6$ \\
Pilot whale 1978 & 15 & $8.91 \pm 2.61$ & $4.45 \pm 1.69$ & $-18.6 \pm 18.8$ \\
Pilot whale 1977 & 10 & $16.45 \pm 8.47$ & $3.17 \pm 1.39$ & $-82.3^{\mathrm{b}}$ \\
\hline
\end{tabular}

${ }^{\text {a }}$ Ocean fish data are from Kaneko and Ralston [21]; pilot whale data are from Julshamn et al. [25]

${ }^{\mathrm{b}}$ Since only the means \pm standard deviations (SD) were available for $\mathrm{Hg}$ and Se of the 1977 pilot whale data, the approximate $\mathrm{Se}-\mathrm{HBV}$ and $\mathrm{HBV}_{\mathrm{Se}}$ for those samples were calculated based on mean values 
$p<0.01)$ related to the weight of the animal. Therefore, increasing $\mathrm{CH}_{3} \mathrm{Hg}$ contents resulted in increasingly negative $\operatorname{HBV}_{\text {Se }}(F=31.9, p<0.0001)$.

\section{Discussion}

Epidemiological and toxicological studies of $\mathrm{CH}_{3} \mathrm{Hg}$ exposures omit consideration of Se as the biochemical "target" of $\mathrm{Hg}$, thus introducing statistical bias, confounding, and imprecision to their assessments. Beneficial effects of improved intakes of nutrients that counteract the adverse effects of maternal $\mathrm{CH}_{3} \mathrm{Hg}$ exposures on fetal outcomes are well recognized [27, 28]. However, the pivotal importance of dietary Se's biochemical role in the mechanism of $\mathrm{CH}_{3} \mathrm{Hg}$ toxicity $[14,19]$ was generally misunderstood and often overlooked.

Predictions of risk based only on $\mathrm{CH}_{3} \mathrm{Hg}$ exposures are inaccurate. The $\mathrm{HBV}_{\mathrm{Se}}$ reflects the Se surplus or deficit in a seafood compared to its $\mathrm{CH}_{3} \mathrm{Hg}$ contents, providing a more reliable index for assessing $\mathrm{CH}_{3} \mathrm{Hg}$ exposure risks. This was evident in a recent animal study that found predictions based on Se-HBV were far more consistent with observed effects than predictions based only on $\mathrm{CH}_{3} \mathrm{Hg}$ exposures [23]. In that study, Se-HBV's relation to toxic effects of $\mathrm{CH}_{3} \mathrm{Hg}$ exposures was highly significant $(F=161.0, p<0.0001)$ and consistent (adjusted $R^{2}=0.735$ ). Predictions based only on $\mathrm{CH}_{3} \mathrm{Hg}$ exposures were less consistent (adjusted $R^{2}=0.158$ ), and their statistical significance was less robust $(F=10.9, p<0.001)$. The crucial difference was the ability of the Se-HBV index to differentially recognize $\mathrm{CH}_{3} \mathrm{Hg}$ exposures that would induce Se deficits potentially severe enough to impair brain selenoenzyme activities from those that would not. In another animal study, $\mathrm{HBV}_{\mathrm{Se}}$, $\mathrm{Se}-\mathrm{HBV}$, and $\mathrm{CH}_{3} \mathrm{Hg}$ exposures were compared as indices of risk. The statistical strength of $\mathrm{HBV}_{\mathrm{Se}}$ and Se-HBV regressors were virtually identical, and both indexes identified adverse effects of $\mathrm{CH}_{3} \mathrm{Hg}$ exposures sooner and with higher $p$ values than assessments performed using only the $\mathrm{CH}_{3} \mathrm{Hg}$ regressor [24].

\section{Role of Background Diet}

Differences in $\mathrm{Hg}$ exposure levels or dietary Se intakes that minimally affect physiological Se status are unlikely to have clinical consequences. However, individuals with poor dietary Se status are more susceptible to the adverse effects from consuming foods with negative $\mathrm{HBV}_{\mathrm{Se}}$ than Se-rich populations. This can explain why studies have reported negative effects from high $\mathrm{CH}_{3} \mathrm{Hg}$ exposures in populations with low dietary Se intakes. For example, a study in New Zealand reported that high $\mathrm{CH}_{3} \mathrm{Hg}$ exposures from maternal consumption of seafoods during pregnancy resulted in negative effects in children [29]. However, this population was known to have an extremely poor Se status [30] making it especially vulnerable to adverse effects from eating foods with a negative $\mathrm{HBV}_{\mathrm{Se}}$. The study indicated that shark fillets with $\mathrm{CH}_{3} \mathrm{Hg}$ contents as high as $4.4 \mathrm{mg} / \mathrm{kg}(\sim 22 \mu \mathrm{mol} / \mathrm{kg})$ and an estimated $\mathrm{HBV}_{\text {Se }}$ as low as -120 were frequently consumed in the form of fish-and-chips [31]. Eating such high- $\mathrm{CH}_{3} \mathrm{Hg}$ fillets would not be recommended for any population, but the reported adverse effects were especially predictable since Se availability to fetal tissue was already compromised by the mothers' extremely low Se status. Conversely, the adverse effects of high $\mathrm{CH}_{3} \mathrm{Hg}$ exposures have been shown to be alleviated or eliminated when diets containing seafoods with a negative $\mathrm{HBV}_{\mathrm{Se}}$ are complemented by Se-rich diets (e.g., from consuming Serich ocean fish) $[32,33]$.

\section{The Contrast Between Hg Exposures from Ocean vs. Freshwater Fish}

Although most ocean fish contain excess Se over their $\mathrm{CH}_{3} \mathrm{Hg}$ contents [21,34], top predators in freshwater with particularly poor Se availability have been shown to accumulate more $\mathrm{CH}_{3} \mathrm{Hg}$ than fish of the same species and size from Se-rich watersheds [35]. This situation is especially notable in areas with high $\mathrm{Hg}$ inputs from local point sources or with inputs of acidic material, which greatly decrease Se bioavailability. Therefore, the fish that have the least amount of Se tend to bioaccumulate the most $\mathrm{CH}_{3} \mathrm{Hg}$. Likewise, increases in amounts of bioavailable Se have been shown to increase $\mathrm{CH}_{3} \mathrm{Hg}$ efflux from fish [36-44] and rapidly diminish their $\mathrm{CH}_{3} \mathrm{Hg}$ body burdens. This mechanism of depuration is augmented by production of insoluble $\mathrm{HgSe}$ in tissues of prey animals at each level of the food web. Because HgSe is highly stable, it passes through the digestive tract unabsorbed and is eliminated, resulting in essentially permanent retirement in the sediments.

Watersheds with low-Se fish occur in various regions of the world. This arises due to Se's poor bioavailability at low $\mathrm{pH}$ [45], poor geological abundance in soils from igneous parent rock materials, or extensive leaching of porous soils by high rainfalls [46]. Since increased $\mathrm{CH}_{3} \mathrm{Hg}$ burdens are associated with lower Se contents in fish [34], regions with freshwater fish potentially having negative $\mathrm{HBV}_{\mathrm{Se}}$ need to be identified. Fish from low-Se watersheds that are concurrently exposed to high $\mathrm{CH}_{3} \mathrm{Hg}$ inputs and acidic waste drainage are therefore expected to have negative $\mathrm{HBV}_{\mathrm{Se}}$. Eating fish from such areas would pose greater risks than consuming Se-rich fish that contain the same amount of $\mathrm{CH}_{3} \mathrm{Hg}$. Because the reference dose and fish consumption advisories are based on $\mathrm{CH}_{3} \mathrm{Hg}$ levels alone, the extent of risk associated with high $\mathrm{CH}_{3} \mathrm{Hg}$ exposures due to eating fish from Se-poor watersheds is currently overlooked. In the absence of dietary Se intakes sufficient to compensate for losses due to $\mathrm{Hg}$ sequestration, high $\mathrm{CH}_{3} \mathrm{Hg}$ exposures are more likely to diminish maternal and fetal Se status. Therefore, consumption of fish with high 
$\mathrm{CH}_{3} \mathrm{Hg}$ contents that arise in areas with poor Se availability is an issue that deserves further study. Fortunately, restoring fish Se concentrations to optimal levels comes with the added benefit of diminishing their $\mathrm{CH}_{3} \mathrm{Hg}$ contents [37-39]. The combined effects of diminishing $\mathrm{CH}_{3} \mathrm{Hg}$ contents while improving the Se status of the aquatic ecosystem would improve the $\mathrm{HBV}_{\mathrm{Se}}$ of the fish. In Se-deficient areas, $\mathrm{CH}_{3} \mathrm{Hg}$ remediation can easily be achieved by augmenting environmental $\mathrm{Se}$ to adequate levels.

\section{Conclusions}

Since the $\mathrm{HBV}_{\mathrm{Se}}$ is based on the biochemical mechanism of $\mathrm{CH}_{3} \mathrm{Hg}$ toxicity, it provides an objective index for assessing the relative effects of $\mathrm{CH}_{3} \mathrm{Hg}$ exposures and dietary Se intakes on Se status. Seafoods with negative values (i.e., pilot whale, certain types of shark, some individual swordfish) are differentiated from ocean fish varieties with positive values. Consumption of seafoods with positive $\mathrm{HBV}_{\mathrm{Se}}$ would negate risks otherwise associated with $\mathrm{CH}_{3} \mathrm{Hg}$ exposures. It is important to note that intermittent $\mathrm{CH}_{3} \mathrm{Hg}$ exposures are unlikely to compromise maternal/fetal Se status, but consistent consumption of negative $\mathrm{HBV}_{\mathrm{Se}}$ seafoods could pose this risk, especially among mothers with poor Se intakes. The $\mathrm{HBV}_{\mathrm{Se}}$ provides a biochemically based perspective that confirms and supports the FDA/EPA advice for pregnant and breastfeeding women regarding seafoods that should be limited vs. those that are beneficial to consume. Since maternal consumption of seafoods has repeatedly been shown to benefit child neurodevelopment, the use of the $\mathrm{HBV}_{\mathrm{Se}}$ provides a reliable, easily understood, and consistent index for identifying healthy seafood choices.

While erring on the side of caution is entirely appropriate when protecting public health, the $\mathrm{HBV}_{\mathrm{Se}}$ may be overly cautious regarding the potential risks of $\mathrm{CH}_{3} \mathrm{Hg}$ exposures from fish consumption. The $\mathrm{HBV}_{\mathrm{Se}}$ conservatively considers only the Se from the fish itself, but dietary $\mathrm{CH}_{3} \mathrm{Hg}$ would also interact with Se from all other dietary sources as well as from host tissue Se reserves. Furthermore, the equation presumes that $\mathrm{CH}_{3} \mathrm{Hg}$ from fish consumption will unfailingly sequester an equivalent amount of $\mathrm{Se}$, but the majority of the $\mathrm{Hg}$ that enters the body will remain bound to thiomolecules during its entire time of residence in the body without encountering or binding cellular Se. This fundamental aspect of $\mathrm{CH}_{3} \mathrm{Hg}$ biochemistry contributes to the prolonged latency between acquiring a toxic dose and the initial onset of signs and symptoms of toxicity [47]. The $\mathrm{HBV}_{\mathrm{Se}}$ is unique in being applicable for assessing risks associated with high exposures to $\mathrm{CH}_{3} \mathrm{Hg}$ as well as in rare circumstances when excessive Se contents of fish is a concern.

The reference dose established for assessing risks associated with $\mathrm{CH}_{3} \mathrm{Hg}$ exposures omits consideration of $\mathrm{Se}$ and is based on effects that were observed in a population which consumed Se-rich diets. Therefore, the reference dose may not be applicable to health consequences that may be associated with elevated $\mathrm{CH}_{3} \mathrm{Hg}$ exposures in Se-poor populations. For that reason, the $\mathrm{HBV}_{\mathrm{Se}}$ of freshwater fish in Se-poor regions warrants study to help identify populations that may experience accentuated risk from consistently consuming fish with negative $\mathrm{HBV}_{\mathrm{Se}}$. A thorough evaluation of $\mathrm{HBV}_{\mathrm{Se}}$ of freshwater fish will enable recognition of locales with varieties that should be avoided or whose consumption should be limited among susceptible subpopulations. Such studies would also indicate where Se augmentation to accomplish $\mathrm{CH}_{3} \mathrm{Hg}$ remediation and restore Se to optimal concentrations would be appropriate.

Acknowledgments The research described in this article was funded by the US Environmental Protection Agency (EPA) National Center for Environmental Research (NCER) Science to Achieve Results (STAR) grant number RD834792-01: Fish Selenium Health Benefit Values in Mercury Risk Management. Funding to cover costs of preparation of this article was provided by the National Fisheries Institute. The sponsors had no role in the study design, collection, analysis, and interpretation of the data, or the decision to submit the article for publication. This article has not been subjected to their review and may not reflect their perspectives. Thus, no official endorsements are implied.

Compliance with Ethical Standards The work described in this manuscript did not involve studies of humans or live animals.

Conflict of Interest The US EPA funded $\sim 98 \%$ of the work described in this article while National Fisheries Institute (NFI) funded $\sim 2 \%$ costs for preparation of the article for publication and travel expenses for the corresponding author to present the findings of this project at the Society of Toxicology (SOT) Meeting in 2013.

\section{References}

1. Pařízek J, Oštádalová I (1967) The protective effect of small amounts of selenite in sublimate intoxication. Experiential 23: $142-143$

2. Pařízek J, Oštádalová I, Kalousková J, Babický A, Pavlík L, Bíbr B (1971) Effect of mercuric compounds on the maternal transmission of selenium in the pregnant and lactating rat. J Reprod Fertil 25: $157-170$

3. Ijima S, Tohyama C, Lu C, Matsumoto N (1978) Placental transfer and body distribution of methylmercury and selenium in pregnant mice. Toxicol Appl Pharmacol 44:143-146

4. Schwarz K, Foltz CM (1957) Selenium as an integral part of factor 3 against dietary necrotic liver degeneration. J Am Chem Soc 79: 3292-3293

5. Wada O, Yamaguchi N, Ono T, Nagahashi M, Morimura T (1976) Inhibitory effect of mercury on kidney glutathione peroxidase and its prevention by selenium. Environ Res 12:75-80

6. Naganuma A, Imura N (1980) Bis(methylmercuric) selenide as a reaction product from methyl-mercury and selenite in rabbit blood. Res Commun Chem Pathol Pharmacol 27:163-173

7. Magos L, Clarkson TW, Hudson AR (1984) Differences in the effects of selenite and biological selenium on the chemical form 
and distribution of mercury after the simultaneous administration of $\mathrm{HgCl}_{2}$ and selenium to rats. J Pharmacol Exp Ther 228:478-483

8. Korbas M, O'Donoghue JL, Watson GE, Pickering IJ, Singh SP, Myers GJ, Clarkson TW, George GN (2010) The chemical nature of mercury in human brain following poisoning or environmental exposure. ACS Chem Neurosci 1:810-818

9. Huggins F, Raverty SA, Nielsen OS, Sharp N, Robertson JD, Ralston NVC (2009) An XAFS investigation of mercury and selenium in beluga whale tissues. Environ Bioindic 4:291-302

10. Falnoga I, Tušek-Žnidarič M, Stegnar P (2006) The influence of long-term mercury exposure on selenium availability in tissues: an evaluation of data. BioMetals 19:283-294

11. Arai T, Ikemoto T, Hokura A, Terada Y, Kunito T, Tanabe S, Nakai I (2004) Chemical forms of mercury and cadmium accumulated in marine mammals and seabirds as determined by XAFS analysis. Environ Sci Technol 38:6468-6474

12. Chen J, Berry MJ (2003) Selenium and selenoproteins in the brain and brain diseases. J Neurochem 86:1-12

13. Schweizer U, Bräuer AU, Josef Köhrle J, Nitsch R, Savaskan NE (2004) Selenium and brain function: a poorly recognized liaison. Brain Res Rev 45:164-178

14. Ralston NVC, Raymond LJ (2010) Dietary selenium's protective effects against methylmercury toxicity. J Toxicol 278:112-123

15. Watanabe C, Yin K, Kasanuma Y, Satoh H (1999) In utero exposure to methylmercury and selenium deficiency converge on the neurobehavioral outcome in mice. Neurotoxicol Teratol 1:83-88

16. Watanabe C, Yoshida K, Kasanuma Y, Kun Y, Satoh H (1999) In utero methylmercury exposure differentially affects the activities of selenoenzymes in the fetal mouse brain. Environ Res 80:208-214

17. Stringari J, Nunes AKC, Franco JL, Bohrer D, Garcia SC, Dafre AL, Milatovic D, Souza DO, Rocha JBT, Aschner M, Farina M (2008) Prenatal methylmercury exposure hampers glutathione antioxidant system ontogenesis and causes long-lasting oxidative stress in the mouse brain. Toxicol Appl Pharmacol 227:147-154

18. Seppänen K, Soininen P, Salonen JT, Lotjonen S, Laatikainen R (2004) Does mercury promote lipid peroxidation? An in vitro study concerning mercury, copper, and iron in peroxidation of lowdensity lipoprotein. Biol Trace Elem Res 101:117-132

19. Carvalho CML, Chew E-H, Hashemy SI, Lu J, Holmgren A (2008) Inhibition of the human thioredoxin system: a molecular mechanism of mercury toxicity. J Biol Chem 283:11913-11923

20. Ralston NVC, Azenkeng A, Ralston CR, Raymond LJ (2014) Selenium-health benefit values as seafood safety criteria. In: Seafood science, Se-Kwon Kim, Ed., CRC Press (in press)

21. Kaneko JJ, Ralston NVC (2007) Selenium and mercury in pelagic fish in the central north Pacific near Hawaii. Biol Trace Elem Res 119:242-254

22. Ralston NVC (2008) Selenium health benefit values as seafood safety criteria. EcoHealth 5:442-455

23. Ralston NVC, Ralston CR, Blackwell JL, Raymond LJ (2008) Dietary and tissue selenium in relation to methylmercury toxicity. Neurotoxicology 29:802-811

24. Ralston NVC, Raymond LJ (2013) EPA progress report: fish selenium-health benefit values in mercury risk management. http://cfpub.epa.gov/ncer_abstracts/index.cfm/fuseaction/display. abstractDetail/abstract/9503/report/2013. Accessed 2 September 2014

25. Julshamn K, Anderson A, Ringdal O, Morkore J (1987) Trace elements intake in the Faroe Islands, I. Element levels in edible parts of pilot whales (Globicephalus meleanus). Sci Total Environ 65:53-62

26. Grandjean P, Weihe P, Jorgenson PJ, Clarkson T, Cernichiari E, Videro E (1992) Impact of maternal seafood diet on fetal exposure to mercury, selenium, and lead. Arch Environ Health 47:185-195

27. Hibbeln JR, Davis JM, Steer C, Emmett P, Rogers I, Williams C, Golding J (2007) Maternal seafood consumption in pregnancy and neurodevelopmental outcomes in childhood (ALSPAC study): an observational cohort study. Lancet 369:578-585

28. Davidson PW, Cory-Slechta DA, Thurston SW, Huang L-S, Shamlaye CF, Gunzler D, Watson G, van Wijngaarden E, Zareba G, Klein JD, Clarkson TW, Strain JJ, Myers GJ (2011) Fish consumption and prenatal methylmercury exposure: cognitive and behavioral outcomes in the main cohort at 17 years from the Seychelles Child Development Study. Neurotoxicology 32:711717

29. Crump KS, Kjellstrom T, Shipp AM, Silvers A, Stewart A (1998) Influence of prenatal mercury exposure upon scholastic and psychological test performance: benchmark analysis of a New Zealand cohort. Risk Anal 18:701-713

30. McKenzie RL, Rea HM, Thomson CD, Robinson MF (1978) Selenium concentration and glutathione peroxidase activity in blood of New Zealand infants and children. Am J Clin Nutr 31: 1413-1418

31. Mitchell JW, Kjellstrom TE, Reeves RL (1982) Mercury in takeaway fish in New Zealand. N Z Med J 95:112-114

32. Budtz-Jørgensen E, Grandjean P, Weihe P (2007) Separation of risks and benefits of seafood intake. Environ Health Perspect 115: 323-327

33. Nakamura M, Hachiya N, Murata K-Y, Nakanishi I, Kondo T, Yasutake A, Miyamoto K-I, Ser PH, Omi S, Furusawa H, Watanabe C, Usuki F, Sakamoto M (2014) Methylmercury exposure and neurological outcomes in Taiji residents accustomed to consuming whale meat. Environ Int 68:25-32

34. Ralston NVC, Raymond LJ (2012) EPA progress report: fish selenium-health benefit values in mercury risk management. http://cfpub.epa.gov/ncer_abstracts/index.cfm/fuseaction/display. abstractDetail/abstract/9503/report/2012. Accessed 2 September 2014

35. Chen YW, Belzile N, Gunn JM (2001) Antagonistic effect of selenium on mercury assimilation by fish populations near Sudbury metal smelters? Limnol Oceanogr 46:1814-1818

36. Turner MA, Rudd JWM (1983) The English Wabigoon River System III. Selenium in lake enclosures: its geochemistry, bioaccumulation, and ability to reduce mercury bioaccumulation. Can J Fish Aquat Sci 40:2228-2240

37. Bjoernberg AA (1989) Decontamination of mercury from Swedish "black-listed" lakes by addition of selenium. In Proceedings of the 4th International Symposium of Uses of Selenium and Tellurium; Carapella SC (ed) Banff, Canada, Selenium-Tellurium Dev. Assoc. Darien, CT, pp 357-60

38. Paulsson K, Lindbergh K (1989) The selenium method for treatment of lakes for elevated levels of mercury in fish. Sci Total Environ 87-88:495-507

39. Glass GE, Sorenson JA, Austin JJ, Schmidt KW, Kallemeyn LW, Hedman SC, Rapp GR (1995) Mitigating mercury in Minnesota lakes and streams. Final report to the Minnesota Pollution Control Agency and Legislative Commission on Minnesota Resources, 1991-1993

40. Bjerregaard P, Andersen BW, Rankin JC (1999) Retention of methyl mercury and inorganic mercury in rainbow trout Oncorhynchus mykiss (W): effect of dietary selenium. Aquat Toxicol 45:171-180

41. Belzile N, Chen Y, Tong J, Gunn JM, Alarie Y, Wu G, Apanna V (2004) The antagonistic role of selenium in mercury bioassimilation by living organisms. In: 7th International Conference on Mercury as a Global Pollutant, Vol. 51, Pezdic J, ed., Ljubljana, RMZ-Materials and Geoenvironment, pp 803-806

42. Bjerregaard P, Fjordside S, Hansen MG, Petrova MB (2011) Dietary selenium reduces retention of methyl mercury in freshwater fish. Environ Sci Technol 45:9793-9798

43. Li Y-F, Dong Z, Chen C, Li B, Gao Y, Qu L, Wang T, Fu X, Zhao Y, Chai Z (2012) Organic selenium supplementation increases mercury excretion and decreases oxidative damage in long-term mercury- 
exposed residents from Wanshan, China. Environ Sci Technol 46: $11313-11318$

44. Mailman M, Bodaly RA, Paterson MJ, Thompson S, Flett RJ (2014) Low-level experimental selenite additions decrease mercury in aquatic food chains and fish muscle but increase selenium in fish gonads. Arch Environ Contam Toxicol 66:32-40

45. Eich-Greatorex S, Sogn TA, Øgaard AF, Aasen I (2007) Plant availability of inorganic and organic selenium fertiliser as influenced by soil organic matter content and pH. Nutr Cycl Agroecosyst 79:221231
46. Gustavsson N, Bølviken B, Smith DB, Severson RC (2001) Geochemical landscapes of the conterminous United States: new map presentations for 22 elements. Professional Paper 1648, U.S. Geological Survey. Available online at: http://pubs.usgs.gov/pp/ p1648/. Accessed 2 September 2014

47. Ralston NVC, Raymond LJ (2015) The "SOS" mechanisms of methylmercury toxicity. In; Selenium in the environment and human health. G.S. Banuelos and Z.-Q. Lin, Eds. Taylor and Francis (London, UK) 